\title{
Translating Idioms Based on the Principle of Equivalence*
}

\author{
WANG Xiao-yan, LI Zhong-zhi \\ Changchun University, Changchun, China
}

\begin{abstract}
It is well-known that it is not easy to translate idioms faithfully, because idioms are the accumulation of different cultures, which presents a lot of difficulties in translating. The present paper, first of all, gives a brief introduction of the factors that how idioms reflect the cultures. They are geographical features, traditional customs, and religious influence. Then the authors of the present paper elaborate the translation principles, especially Nida's Principle of Equivalence. At last, three strategies of translating idioms based on the Principle of Equivalence are explored. They are literal translation, partially literal translation, and free translation or paraphrase. The paper concludes that the translation of idioms should aim not only at formal equivalence, but also at dynamic equivalence. The authors hope that the present paper can give some help to the translation of idioms.
\end{abstract}

Keywords: translation, idioms, the Principle of Equivalence

\section{Introduction}

Idioms are semantically and structurally fixed expressions which, in essence, are kind of accumulation of culture. Take Chinese for example, over thousands of years, Chinese people has gradually formed their own language on the basis of their specific living and thinking habit. Each generation does not absolutely accept the cultural heritage of the last generation. Instead, they both develop what is useful and discard what is not. In this process, the essence culture in the past is retained in language and passed on as fixed language expressions. How idioms distinctively reflect a nation' s culture rests on the following factors.

\section{Geographical Features}

A given cultural entity exists in a given geographical space, therefore, it unavoidably reflects the features of the region. Different regions with different scenes have particular characteristics. In language expressions, there is a striking contrast when natural landscapes are used metaphorically. For instance, in the Chinese idiom 有眼 不识泰山 (fail to recognize a great person), “泰山” is a famous mountain and here is used to refer to the VIPs (very important persons). Any foreigners with scant knowledge of Chinese culture can hardly catch the meaning expressed here. Other examples like: 不到黄河不死心 (refuse to give up until all hope is gone). Here “黄河 (the Yellow River)” is peculiar Chinese geographical culture. It is the same as the English idioms which reflect a certain feature of a region as well, such as, talk like a Dutch uncle (谆谆教诲), shoot Niagara (孤注一郑), and

\footnotetext{
* Acknowledgements: This paper is a part of the results of the research program the authors have participated in "The Study of the Relationship Between Russian Tartar and Mongolian Civilization” (2013, No. 261).

WANG Xiao-yan, associate professor, School of Foreign Languages, Changchun University.

LI Zhong-zhi, associate professor, School of Foreign Languages, Changchun University.
} 
take a French leave (不辞而别). For a better understanding and using of these idioms, one needs to find out the features of the word used metaphorically.

\section{Traditional Customs}

In Chinese culture, the animal “马 (horse)" seems to be frequently used commendatory like in 骏马 (fine horse/steed), 马到成功 (accomplish immediately success), and 老马识途 (an old horse knows the way). This usage is traditionally related to the importance of horses in Chinese history. As an agricultural nation, horses, at one time, have been assistants of farmers. That is why Chinese nation is so in favor of horses.

However, in English, “horse” is more often used neutrally like the idioms: eat like a horse (吃得非常多), work like a horse (辛苦地干活), and beat a dead horse (死马当作活马医).

A nation that is enthusiastic about horse race also has a host of idioms with "horse", but horse is still considered as neutral. Such as: bet on the wrong horse (支持错了对象), that is a horse of another color (那是另 一回事), and a dark horse (实力难测的赛马).

\section{Religious Influence}

It is evident that Chinese nation is also influenced by religion. In idioms: 一个和尚挑水吃，两个和尚抬 水吃, 三个和尚没水吃 (One boy is a boy, two boys half a boy, three boys no boy). It is attached to religious features and it is used metaphorically.

During the medieval period, Christianity almost extended to every aspect of English speaking nations so that there are idioms like: as poor as the church mouse (一贫如洗), Man proposes, God disposes (谋事在人, 成事 在天), make a god of one’s belly (一味追求吃喝), and Go to hell (见鬼去吧).

From the above, it is not hard to see that language and culture are closely related. Because of the cultural differences, there must be difficulty in translating idioms, and how to translate idioms has been the heavy task for translator. In the present paper, the author is going to explore how to translate the idioms in the light of the Principle of Equivalence.

\section{The Principle of Equivalence}

In 1780, Tytler wrote the first significant book on translation in the world: Essay on the Principles of Translation, and presented three main principles: (1) Translation text should fully express the idea of the original text; (2) The writing tones and styles should be the same; and (3) The translation text should be with ease and grace (as cited in ZHAO, 2008, p. 15). He held the view that the excellent translation works can make the readers have the same understanding as the native readers. In 1965, the English linguist Catford published a book called A Linguistic Theory of Translation. He classified translation into three ways: word for word translation, literal translation, and free translation. Linguistic surface structure is divided into a scale of sentences-sense groups-words-morphemes. In free translation, the equivalence may cover each element in the scale, even extends to sentences. Word for word translation, obviously, limits between words. While literal translation is between word for word translation and free translation. Newmark (1991) presented two translation methods: communicative translation and semantic translation. The former aims at making the readers have the same idea no matter they read the original work or the translation work. The latter aims at reproducing the information of the source language on the basis of complying with the grammatical and semantic rules. These 
two methods are used alternatively. Baker in her book In Other Words: A Coursebook on Translation (2000) offered a detailed list of conditions upon which the concept of equivalence can be defined. She studied the equivalence at different levels: equivalence at word level, equivalence above word level, grammatical equivalence, textual equivalence, and pragmatic equivalence.

In addressing the concept of equivalence in translation, Nida (1964) claimed that: "There can be no absolute correspondence between languages" (p. 136). Then he put forward the notion of "dynamic equivalence” in translation:

In dynamic translation one is not so concerned with marching the receptor-language message with the source 1anguage message, but with the dynamic relationship, that the relationship between receptor and message should be substantially the same as that which existed between the original receptors and the message. (Nida, 1964 , p. 159)

Dynamic equivalence is therefore to be defined in terms of the degree to which the receptors of the message in the receptor language respond to it in substantially the same manner as the receptors in the source language. Up to 1990s, Nida took cultural differences into consideration and categorized it into maximal level and minimal level. As a matter of fact, the former is not easy to achieve in translation but every translation should be up to the latter criteria. As Nida illustrated that, the minimal level of equivalence would be one in which receptors of the translated text would be able to understand and appreciate it to the point of being able to comprehend how the original receptors must have understood and appreciated the message. At last, Nida emphasized that equivalence is a relative conception. He explained that in attempting to produce a dynamic rather a formal equivalence in translation, "principle of equivalence is necessary” (Nida, 1998, p. 80).

\section{The Translation of Idioms: Strategies}

Idioms, refined and sanctified from long usage, are vivid and expressive. They are crystallization of national culture and gems of language. Like a mirror, they reflect the national characteristics embodied in a language and are thus heavily color-added. Different national cultures lead to various idioms of a given speech community. This culture differences present a lot of difficulties in translating. But idiom is a part of language and it is proved that idioms can be translated. Generally, there are three ways as follows.

\section{Totally Literal Translation}

This strategy involves using an idiom in the target language which conveys roughly the same meaning as that of the source-language idiom and, in addition, consists of equivalent lexical items. This kind of match can only occasionally be achieved. We know in translation, it is not hard to transfer meaning but to keep the original flavor is not easy. Some idioms can be translated literally. For example, 丢脸 (lose face), 药补不如食补 (diets cares more than the doctors), 巧妇不做无米之炊 (even the cleverest housewife cannot cook a meal without rice), 大树底下好乘凉 (a good tree is a good shelter), 条条道路通罗马 (all roads, lead to Rome), 得寸进尺 (give him an inch and he will take a mile), 滴水穿石 (constant dropping wears the stone), 混水摸鱼 (fish in troubled waters), 磨洋工 (lie down on the job), 千钧一发 (hang by a thread), 一帆风顺 (plain sailing), 洗手 不干 (wash one's hands of), and 肤浅 (skin deep).

The above translations take both form and content into consideration. For the target language, readers are more likely to have the equivalence. 


\section{Partially Literal Translation}

Idioms, generally, have three layers of meaning: the literal meaning, the image, and the implicit meaning. So it is often possible to find an idiom in the target language which has a meaning similar to that of the source idiom, but which consists of different lexical items. In form, there is difference between the source language and the target language. For example, 红颜多薄命 (beautiful flowers are soon picked), 情不分贫富 (love lives in cottages as well as in courts), 知人知面不知心 (you can know a man's face but not his heart), 当着矮人不说 矮话 (one does not talk about midgets in front of dwarfs), 初生牛犊不怕虎 (new born calves do not fear wolves), 进退维谷 (between the devil and the deep sea), 害群之马 (a black sheep), 拦路虎 (a lion in the way), and 喜马拉雅山羚羊, 是野生山羊的一种, 在四川的多岩断层露头之间优游自在 (the serow, a type of wild mountain goat, is totally at ease in Sichuan's may rocky levels).

The meanings of these idioms between Chinese and English are similar, but they have different images and dissimilar forms. Especially in the last example, the Chinese idiom “优游自在” consists of two set phrases “优 游” and “自在”, which almost carry the same meaning. So in English, we can use the similar idiom “totally at ease". So in translation, we need to consider the similar and dissimilar meaning and forms of the idioms in both the source and the target languages.

\section{Free Translation or Paraphrase}

This is by far the most common way of translating idioms when a match cannot be found in the target language, or when it seems inappropriate to use idiomatic language in the target text because of differences in stylistic preferences of the source and target languages. Sometimes the above-mentioned two ways fail to express the meaning of idioms. Then free translation or paraphrase is needed. Successful free translation or paraphrase is to change the linguistic symbols in order to transfer meaning. For examples, 有眼不识泰山 (fail to recognize one's eminence), 雨后春笋 (new things appear and grow rapidly), 雪中送炭 (provide timely help), 不到黄河 不死心 (refuse to give up until all hope is gone), 开玩笑 (pull one's leg), 处于困境 (in the same boat), 处于 危险境地 (to be touch and go), and 非常恐惧 (one’s hair stands on end).

These idioms should be translated with caution. Their images are similar, but the meanings differ. So under the guidance of equivalent principle, the translating versions produce a dynamic rather a formal equivalence in translation, and the receptors of the translated text would be able to understand and appreciate it to the point of being able to comprehend how the original receptors must have understood and appreciated the message.

\section{Conclusions}

Idioms are the cream of language as well as the crystallization of human wisdom, which carries profound cultural implication. As a language, idiom is the essence of the deposition of the fascinating history and culture. Because of the differences in geography, history, religion, customs, and other aspects of life between Chinese and English, idioms carry the characteristics of different cultures and cultural information. So in translation, people have to encounter many difficulties, and the change of one linguistic form into another is only surface work; the transfer of cultural information is the nature of translation. Surely, idioms reflect the specific culture of a certain speech community, yet with more and more international communication, people have begun to narrow the margin of cultural divergence. The paper concludes that the translation of idioms should aim not only at formal 
equivalence, but also at dynamic equivalence. The task of translators is to overcome cultural differences so as to achieve effective translation with a higher degree of equivalence.

\section{References}

Baker, M. (2000). In other words: A coursebook on translation. Beijing: Foreign Language Teaching and Research Press. Catford, J. C. (1965). A linguistic theory of translation. Oxford: Oxford University Press.

JIAO, L. (2012). The application of cooperative principle in translation. Overseas English, 3, 184.

JIN, D., \& Nida, E. A. (2006). On translation—An expanded edition. Hong Kong: City University of Hong Kong Press.

Newmark, P. (1991). About translation (p. 87). London: Multilingual Matters Ltd..

Nida, E. A. (1964). Toward a science of translation (pp. 69-146). Leiden: E. J. Brill.

Nida, E. A. (1982). The theory and practice of translation (pp. 47-49). Leiden: E. J. Brill.

Nida, E. A. (1986). A functional approach to problems of translating: Foreign language and their teaching (pp. 88-90). Leiden: E. J. Brill.

Nida, E. A. (1998). Language, culture and translating (pp. 79-81). Shanghai: Shanghai Foreign Language Teaching Education Press.

Nida, E. A. (2000). Principles of correspondence. In L. Venuti (Ed.), The translation studies reader (pp. 126-130). London and New York: Routledge.

ZHAO, N. (2008). Applying the dynamic equivalence principle in translation of the heading of the newsreport. Science and Technology Information, (25), 575. 